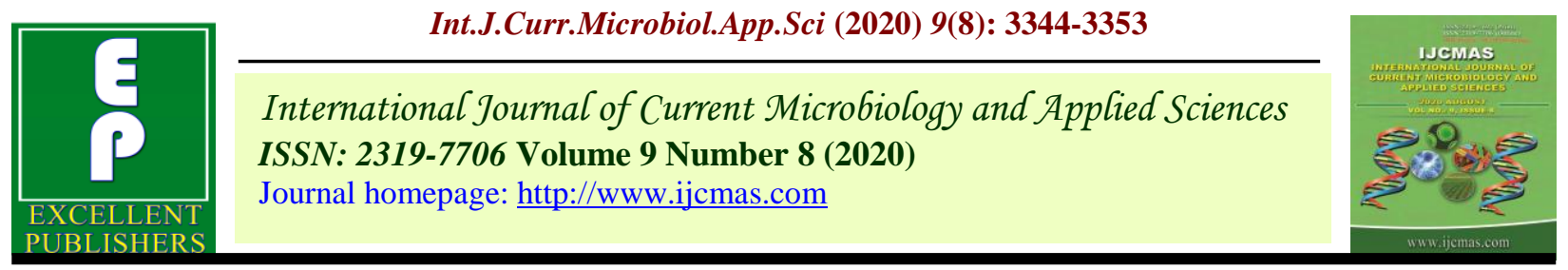

Original Research Article

https://doi.org/10.20546/ijcmas.2020.908.385

\title{
Cultural and Morphological Variability among the Isolates of Colletotrichum spp. Causes Fruit Rot of Papaya
}

\author{
H. N. Prajapati ${ }^{1}$ and R. K. Patil ${ }^{2}$ \\ ${ }^{1}$ College of Horticulture, Anand Agricultural University, Anand-388110, Gujarat, India \\ ${ }^{2}$ Department of plant Pathology, B. A. College of Agriculture, Anand Agricultural University \\ Anand, Gujarat, India \\ *Corresponding author
}

\section{A B S T R A C T}

Papaya is prone to many diseases incited by fungi, bacteria, nematodes and viruses leading to enormous loss in yield. Among all, papaya anthracnose incited by Colletotrichum gloeosporioides (Penz.) Penz. \& Sacc. appear to

Keywords

Colletotrichum,

Fruit rot, Papaya,

Cultural characters

Article Info

Accepted:

26 July 2020

Available Online:

10 August 2020 be more severe causing substantial losses to papaya fruits during transit and storage. Papaya anthracnose is the most important disease throughout the year in India and it became a major limiting factor in papaya cultivation. Total nineteen isolates of Colletotrichum spp. studied for their cultural characters at $2^{\text {nd }}, 4^{\text {th }}, 6^{\text {th }}$ and $8^{\text {th }}$ day after incubation. Significantly highest mycelial growth of Colletotrichum spp. after 4 days was recorded in isolate Cd-8. After $8^{\text {th }}$ day of incubation, significantly highest mycelial growth was recorded in isolates Cd-13 and Cd-15 $(90.00 \mathrm{~mm})$. Significantly highest length and breadth of conidia were recorded in an isolate Cd-13 (26.97 \& $5.57 \mu \mathrm{m})$ and $\mathrm{Cd}-8(25.40 \& 5.33 \mu \mathrm{m})$ as compare to other isolates. Significantly maximum number of setae per acervulus was recorded in isolate Cd-13 (32.00) over all other isolates.

\section{Introduction}

The papaya is the fruit of the plant Carica papaya L., the sole species in the genus Carica of the family Caricaceae. It is native of tropical America. It was first cultivated in Mexico (Anon, 2012a). The popularity of papaya fruit has made it ubiquitous in tropical and subtropical regions of the world. It has made its way from kitchen gardens to the commercial orchards in many tropical and subtropical countries because of its highest production of fruits (75 to 100 tons ha ${ }^{-1}$ ) and stood next to banana in income (Thamaraikannan and Sengottuvel, 2012).

Pramod et al., (2007) recorded 5.42 to 10.37 per cent disease incidence due to Colletotrichum gloeosporioides in papaya at Coimbatore markets. Rahman et al., (2008) reported 90 to 98 Per cent incidence and 25 to 38 per cent losses of papaya yield due to 
anthracnose disease caused by $C$. gloeosporioides in Malaysia.

\section{Materials and Methods}

\section{Collection, isolation and purification}

Fresh naturally infected diseased papaya fruits showing typical characteristic symptoms of Colletotrichum fruit rot were collected from the Sardar Patel vegetable market, Anand and brought to the laboratory in paper bags for isolation of the pathogen. Small pieces of diseased tissues along with adjoining healthy tissues were cut and surface sterilized by dipping in 0.1 per cent $\mathrm{NaOCl}$ solution for one minute followed by three successive washings with distilled sterile water and these pieces were placed on Potato Dextrose Agar (PDA) medium $(20 \mathrm{ml})$ poured in Petri plates under aseptic condition. The inoculated plates were incubated for growth of the pathogen at $25 \pm 10 \mathrm{C}$ in BOD incubator for seven days.

\section{Cultural variability}

To study the cultural variability of the isolates of Colletotrichum sp. was grown on PDA medium sterilized in autoclave for 20 minutes at $15 \mathrm{lbs}$ p.s.i. The $5 \mathrm{~mm}$ disc of pure culture of each isolate was inoculated separately at the center of the pre poured Petri plates from seven days old actively growing culture. All inoculated plates were incubated at $25 \pm 1{ }^{\circ} \mathrm{C}$ temperature in BOD incubator. Three replications were kept for each isolate. The mycelial growth rate of each isolate was measured after 8 days of incubation. The observations were recorded on cultural characteristics like colony colour and growth pattern after eight days of incubation.

\section{Morphological variability}

The morphological characters like size (length and width) shape of the conidia, size and total number of acervuli, size and number of setae per acervuli. The observations were recorded in three repetitions within each isolate. The study was carried out using ocular and stage micrometer after mounting them on the slides containing sterile distilled water at magnification of $40_{X}$.

\section{Results and Discussion}

\section{Cultural variability}

Total nineteen isolates of Colletotrichum spp. studied for their cultural characters at $2^{\text {nd }}, 4^{\text {th }}$, $6^{\text {th }}$ and $8^{\text {th }}$ day of incubation. The colony colour and growth pattern of isolates were recorded after eight days of incubation (Table $1 \& 2)$.

\section{After $2^{\text {nd }}$ day}

After $2^{\text {nd }}$ day of incubation, significantly highest mycelial growth of Colletotrichum spp. was found in isolate $\mathrm{Cd}-13(21.53 \mathrm{~mm})$. The next best isolate was Cd-12 $(20.60 \mathrm{~mm})$ and it was at par with isolate Cd-8 (19.87 $\mathrm{mm})$. The isolate Cd-19 gave $19.53 \mathrm{~mm}$ mycelial growth after 2 days of incubation which was at par with $\mathrm{Cd}-1, \mathrm{Cd}-15$ and $\mathrm{Cd}-3$ with $19.50,18.86$ and $18.77 \mathrm{~mm}$ mycelial growth respectively. The isolate $\mathrm{Cd}-9$ gave $18.50 \mathrm{~mm}$ mycelial growth which was at par with isolate $\mathrm{Cd}-11(18.00 \mathrm{~mm})$ and $\mathrm{Cd}-10$ (17.87). The next isolate with respect to mycelial growth was Cd-5 $(17.60 \mathrm{~mm})$ which was at par with isolate $\mathrm{Cd}-4(17.53 \mathrm{~mm})$ and Cd-18 (17.47 mm). Significantly lowest mycelial growth was recorded in isolate $\mathrm{Cd}$ $16(11.83 \mathrm{~mm})$

\section{After $4^{\text {th }}$ day}

Significantly highest mycelial growth of Colletotrichum spp. after 4 days was recorded in isolate Cd-8 and it was at par with isolate Cd-19, Cd-13 and Cd-1 producing 47.33, $46.43,46.30$ and $45.70 \mathrm{~mm}$ mycelial growth, respectively. The next best treatment in order 
of merit was Cd-10 (44.03 mm) and it was at par with isolate $\mathrm{Cd}-9$ (43.93 $\mathrm{mm}), \mathrm{Cd}-3$ (42.80mm), Cd-15 (42.33mm), Cd-12 (41.33) and Cd-11 (41.30). The isolate Cd-18, Cd-4, $\mathrm{Cd}-17$, and $\mathrm{Cd}-5$ produced 40.01, 39.37, 38.13 and $37.90 \mathrm{~mm}$ mycelial growth, respectively. Significantly lowest mycelium growth of Colletotrichum spp. was recorded in isolate $\mathrm{Cd}-16(28.33 \mathrm{~mm})$.

\section{After $6^{\text {th }}$ day}

After $6^{\text {th }}$ day of incubation, the highest mycelium growth was recorded in isolate $\mathrm{Cd}$ $13(68.03 \mathrm{~mm})$ which was at par with isolate Cd-1 and Cd-15 with 67.23 and $66.10 \mathrm{~mm}$ mycelium growth, respectively. The next best isolates were $\mathrm{Cd}-19(64.03 \mathrm{~mm})$, and it was at par with isolate $\mathrm{Cd}-8, \mathrm{Cd}-3$ and $\mathrm{Cd}-4$ with $63.77,63.20$ and $61.80 \mathrm{~mm}$, respectively. The isolate $\mathrm{Cd}-10$ produced $61.24 \mathrm{~mm}$ mycelial growth which was at par with isolate Cd-18, Cd-5 and Cd-9 with 61.10, 60.00 and 59.20 $\mathrm{mm}$ growth, respectively. Significantly lowest mycelia growth was recorded in isolate $\mathrm{Cd}-16$ $(41.03 \mathrm{~mm})$.

\section{After $8^{\text {th }}$ day}

Significantly highest mycelial growth $(90.00$ $\mathrm{mm}$ ) were recorded in isolates $\mathrm{Cd}-13$ and $\mathrm{Cd}$ 15 which was at par with $\mathrm{Cd}-1, \mathrm{Cd}-8$ and $\mathrm{Cd}-$ 19 with $89.67,89.00$ and $85.77 \mathrm{~mm}$ mycelium growth, respectively. The next best isolate in order of merit was Cd-3 $(85.33 \mathrm{~mm})$ which was at par with $\mathrm{Cd}-4(83.33 \mathrm{~mm})$ and $\mathrm{Cd}-18$ $(83.10 \mathrm{~mm})$. The isolate $\mathrm{Cd}-5$ and $\mathrm{Cd}-17$ produced $80.67 \mathrm{~mm}$ and $80.43 \mathrm{~mm}$ mycelium growth, respectively. Significantly lowest mycelium growth was recorded in isolate $\mathrm{Cd}$ $16(56.00 \mathrm{~mm})$.

\section{Morphological variability}

Observations on size of conidia and number of setae per acervulus produced by each isolate were recorded by microscopic observations (Table 3).

\section{Length of conidia $(\mu \mathrm{m})$}

Significantly highest length of conidia were recorded in isolate $\mathrm{Cd}-13(26.97 \mu \mathrm{m})$ and $\mathrm{Cd}-$ $8(25.40 \mu \mathrm{m})$ as compare to other isolates. The next best isolate in order of merit was Cd-3 $(22.67 \mu \mathrm{m})$ and was at par with isolate Cd-16 $(22.00 \mu \mathrm{m})$ and Cd-1 $(21.30 \mu \mathrm{m})$. The isolate $\mathrm{Cd}-18, \mathrm{Cd}-4, \mathrm{Cd}-17, \mathrm{Cd}-10$ and $\mathrm{Cd}-12$ recorded 18.80, 17.90, 17.73, 17.50 and 17.33 $\mu \mathrm{m}$ length of conidia, respectively. Significantly lowest length of conidia was recorded in isolate Cd-5 $(12.23 \mu \mathrm{m})$.

\section{Width of conidia $(\mu \mathrm{m})$}

Significantly highest width of conidia was recorded in isolate $\mathrm{Cd}-13(5.57 \mu \mathrm{m})$ and was at par with isolate $\mathrm{Cd}-8(5.33 \mu \mathrm{m})$. The next best isolate in order of merit was $\mathrm{Cd}-3$ with $5.10 \mu \mathrm{m}$ width and it was at par with $\mathrm{Cd}-16$, Cd- 1 and Cd-18 with $5.00,4.97$ and $4.90 \mu \mathrm{m}$ width, respectively. The isolate $\mathrm{Cd}-12$ has $4.63 \mu \mathrm{m}$ width, which was at par with isolate Cd-17 $(4.57 \mu \mathrm{m})$ and Cd-4 $(4.40 \mu \mathrm{m})$. Isolate Cd-19 recorded $3.90 \mu \mathrm{m}$ width and it was at par with isolate Cd-14 (3.80 $\mu \mathrm{m}), \mathrm{Cd}-7$ (3.57 $\mu \mathrm{m}), \mathrm{Cd}-5(3.57 \mu \mathrm{m})$ and Cd-6 (3.53 $\mu \mathrm{m})$.

\section{No. of setae/ acervulus}

Significantly highest number of setae per acervulus was recorded in isolate Cd-13 (32.00) over all other isolates. The next best isolate in order of merit was Cd-8 (28.80) which was at par with Cd-15 (27.33). The isolate Cd-3 produced 26.07 setae per acervulus. The next best isolate for acervulus production was $\mathrm{Cd}-19$ (23.03) which was at par with isolate $\mathrm{Cd}-18, \mathrm{Cd}-7, \mathrm{Cd}-12, \mathrm{Cd}-1$ and $\mathrm{Cd}-17$ with 22.53, 22.43, 22.33, 22.30 and 21.67 , respectively. 
Int.J.Curr.Microbiol.App.Sci (2020) 9(8): $3344-3353$

Table.1 Cultural growth variability among the isolates of Colletotrichum spp.

\begin{tabular}{|c|c|c|c|c|}
\hline \multirow[t]{2}{*}{ Isolate } & \multicolumn{4}{|c|}{ Colony diameter (mm) } \\
\hline & $2^{\text {nd }}$ day & $4^{\text {th }}$ day & $6^{\text {th }}$ day & $8^{\text {th }}$ day \\
\hline Cd-1 & 19.50 & 45.70 & 67.23 & 89.67 \\
\hline Cd -2 & 14.30 & 35.23 & 55.50 & 67.00 \\
\hline Cd -3 & 18.77 & 42.80 & 63.20 & 85.33 \\
\hline $\mathrm{Cd}-4$ & 17.53 & 39.37 & 61.80 & 83.33 \\
\hline Cd -5 & 17.60 & 37.90 & 60.00 & 80.67 \\
\hline Cd -6 & 14.30 & 32.63 & 53.74 & 67.18 \\
\hline $\mathrm{Cd}-7$ & 15.40 & 34.08 & 52.60 & 67.93 \\
\hline Cd -8 & 19.87 & 47.33 & 63.77 & 89.00 \\
\hline Cd -9 & 18.50 & 43.93 & 59.20 & 75.83 \\
\hline Cd -10 & 17.87 & 44.03 & 61.24 & 76.66 \\
\hline Cd -11 & 18.00 & 41.30 & 52.57 & 68.80 \\
\hline Cd -12 & 20.60 & 41.33 & 54.73 & 69.60 \\
\hline Cd -13 & 21.53 & 46.30 & 66.10 & 90.00 \\
\hline Cd -14 & 14.400 & 33.50 & 52.10 & 66.96 \\
\hline Cd -15 & 18.86 & 42.33 & 68.03 & 90.00 \\
\hline Cd -16 & 11.83 & 28.33 & 41.03 & 56.00 \\
\hline Cd -17 & 16.17 & 38.13 & 55.00 & 80.43 \\
\hline Cd -18 & 17.47 & 40.01 & 61.10 & 83.10 \\
\hline Cd -19 & 19.53 & 46.43 & 64.03 & 85.77 \\
\hline S.Em. \pm & 0.28 & 1.03 & 0.79 & 1.51 \\
\hline C.D. at $5 \%$ & 0.80 & 2.95 & 2.26 & 4.33 \\
\hline C.V. \% & 2.75 & 4.46 & 2.34 & 3.37 \\
\hline
\end{tabular}


Table. 2 Cultural characters of Colletotrichum spp. isolates at $25 \pm 2{ }^{\circ} \mathrm{C}$ on potato dextrose agar after 8 days of incubation

\begin{tabular}{|c|c|c|}
\hline Isolates & Colony colour & Growth pattern \\
\hline Cd-1 & Dark gray & Circular, flat and suppressed \\
\hline Cd -2 & Whitish pink to gray & Fluffy, radial growth \\
\hline Cd -3 & Light grayish & Circular, flat and suppressed \\
\hline Cd -4 & Dull ash to gray colour & Circular to oval and fluffy \\
\hline Cd -5 & $\begin{array}{l}\text { Dirty white at centre and white at } \\
\text { margin }\end{array}$ & Olive, fluffy and circular \\
\hline Cd -6 & Dark whitish & Suppressed and circular \\
\hline Cd -7 & Whitish to light green & Scattered and circular \\
\hline Cd -8 & White grayish & Scattered and circular \\
\hline Cd -9 & Whitish with gray dots & Flattened and circular \\
\hline Cd -10 & Whitish gray to dark gray at centre & Suppressed and radial \\
\hline Cd -11 & Black colour at centre & Flattened and circular \\
\hline Cd -12 & Dirty white with greenish centre & Raised circular fluffy growth \\
\hline Cd -13 & Dark gray & Flattened and circular \\
\hline Cd -14 & Dirty white & Suppressed and circular \\
\hline Cd -15 & Milky white with gray centre & Radial, suppressed and flat \\
\hline Cd -16 & Pinkish white & Circular and fluffy growth \\
\hline Cd -17 & Milky white & Flattened and circular \\
\hline Cd -18 & Whitish pink & Radial and flat \\
\hline Cd -19 & White with gray centre & Circular and flat \\
\hline
\end{tabular}


Table.3 Morphological characters (length and width, $\mu \mathrm{m}$ ) of conidia and No. of setae/Acervulus of Colletotrichum spp. isolates

\begin{tabular}{|c|c|c|c|}
\hline \multirow[t]{2}{*}{ Isolates } & \multicolumn{2}{|c|}{ Size of conidia $(\mu \mathrm{m})$} & \multirow{2}{*}{$\begin{array}{l}\text { No. of setae } \\
\text { acervulus }\end{array}$} \\
\hline & Length & Width & \\
\hline Cd-1 & 21.30 & 4.97 & 22.30 \\
\hline Cd -2 & 13.20 & 3.13 & 18.20 \\
\hline Cd -3 & 22.27 & 5.10 & 26.07 \\
\hline Cd -4 & 17.90 & 4.40 & 19.23 \\
\hline Cd -5 & 12.23 & 3.57 & 16.40 \\
\hline Cd -6 & 15.63 & 3.53 & 17.13 \\
\hline Cd -7 & 12.50 & 3.57 & 22.43 \\
\hline Cd -8 & 25.40 & 5.33 & 28.80 \\
\hline Cd -9 & 14.73 & 3.63 & 15.70 \\
\hline Cd -10 & 17.50 & 3.47 & 19.23 \\
\hline Cd -11 & 13.77 & 2.13 & 16.77 \\
\hline Cd -12 & 17.33 & 4.63 & 22.33 \\
\hline Cd -13 & 26.97 & 5.57 & 32.00 \\
\hline Cd -14 & 13.63 & 3.80 & 14.00 \\
\hline Cd -15 & 13.10 & 3.43 & 27.33 \\
\hline Cd -16 & 22.00 & 5.00 & 18.33 \\
\hline Cd -17 & 17.73 & 4.57 & 21.67 \\
\hline Cd -18 & 18.80 & 4.90 & 22.53 \\
\hline Cd -19 & 13.90 & 3.90 & 23.03 \\
\hline S.Em \pm & 0.47 & 0.14 & 0.54 \\
\hline C.D. at $5 \%$ & 1.35 & 0.41 & 1.54 \\
\hline C.V. \% & 4.71 & 5.71 & 4.39 \\
\hline
\end{tabular}




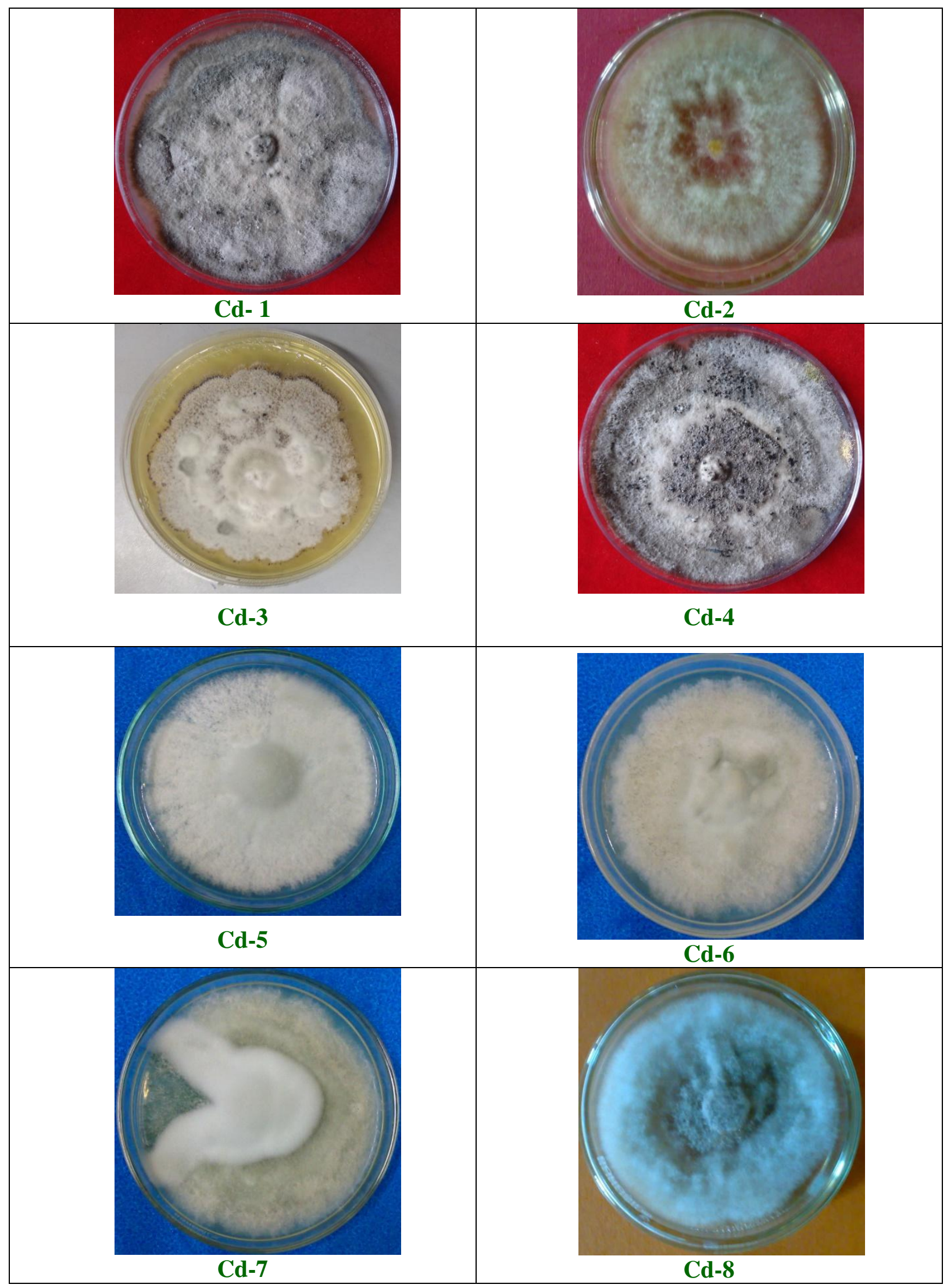


Int.J.Curr.Microbiol.App.Sci (2020) 9(8): 3344-3353

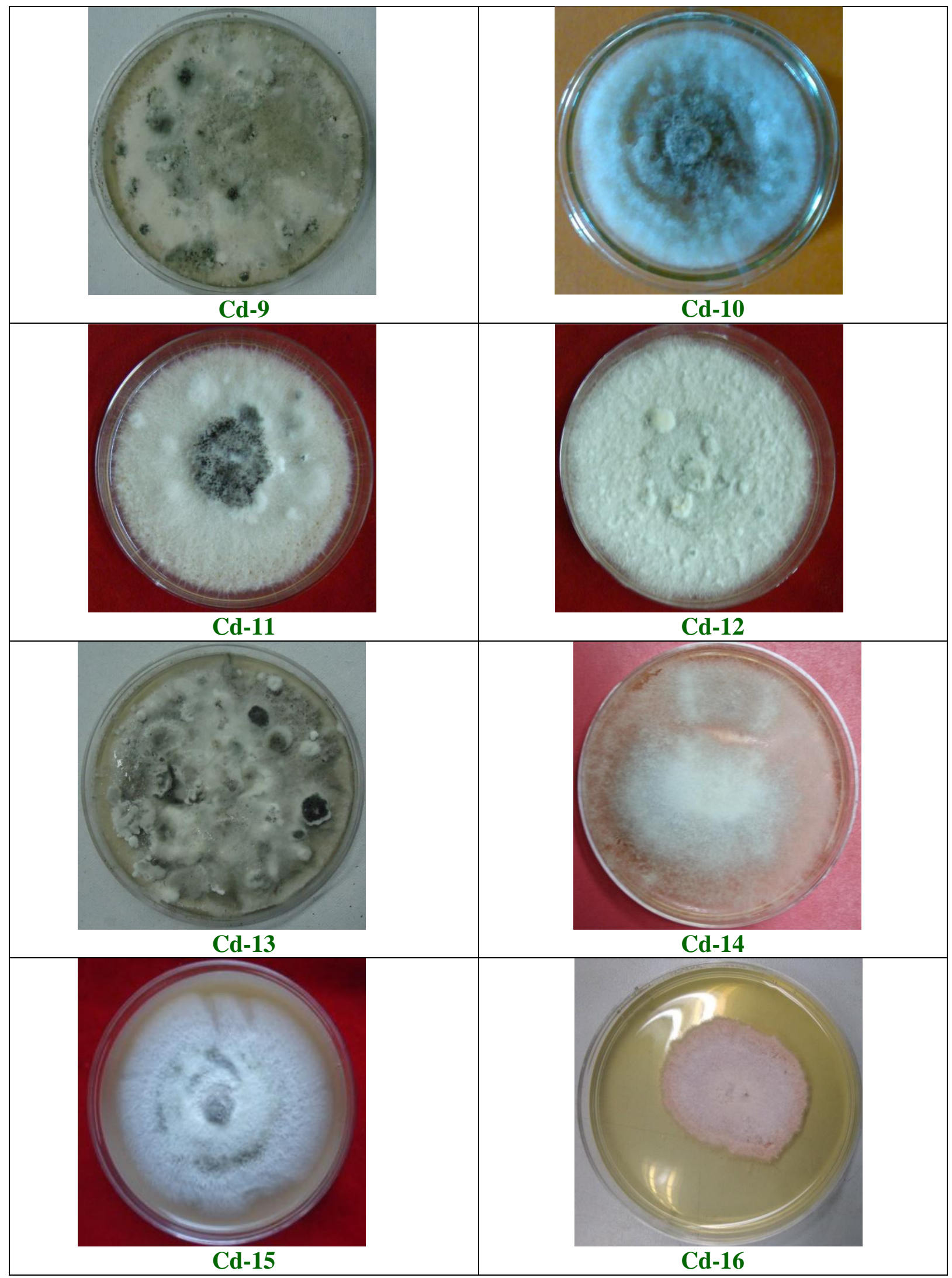




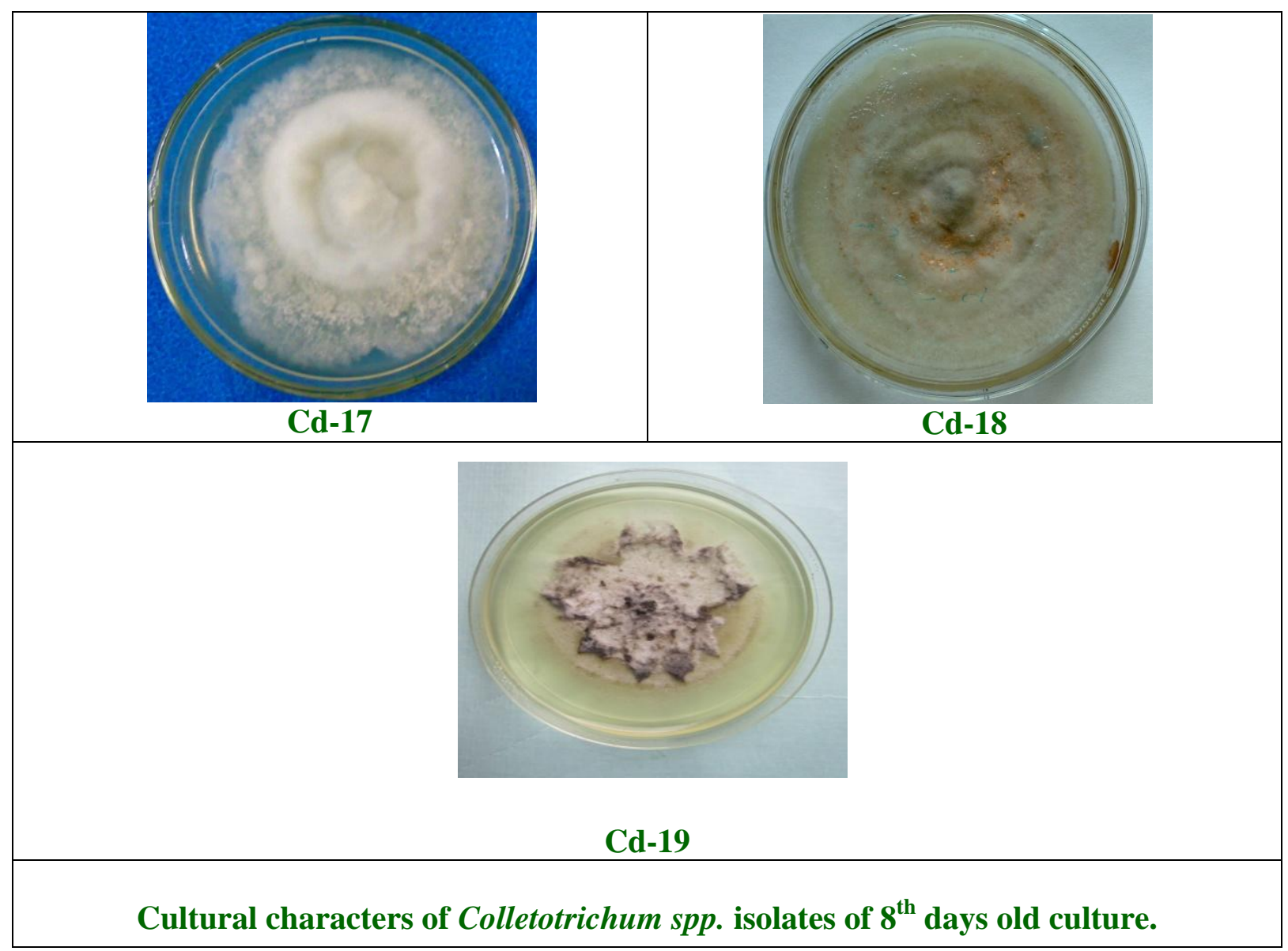

Results in agreement to the present finding were reported by Peres et al., (2002). They studied various cultural and morphological characteristics of Colletotrichum spp. isolates in Brazil. They categorized the Colletotrichum spp. isolated from papaya fruits based on conidial size, conidial shape and colony colour. Damm et al., (2009) categorized Colletotrichum demaitum as ahyaline, aerial, medium close to stem stained pale honey and margins of filter paper gray colour mycelium. After 7 days, colony size and colour of the conidial masses and zonation was recorded and conidial size and shape of 20 arbitrary conidia were measured under the microscope. Papaya isolate showed cylindrical shape of conidia with 17.7and 6.4 $\mu \mathrm{m}$ mean length and width, respectively (Phoulivong et al., 2010).

\section{References}

Anonymous (2012a). http:// nhb.gov.in/ Horticulture/ 20 Crops/ Papaya

Thamaraikannan, M. and Sengottuvel, C. (2012). Papaya cultivation and export, Facts for you, December-2012, pp. 2124.

Peres, N. A. R., Kuramae, E. E., Dias, M. S. C. and Souza, N. L. (2002). Identification and characterization of Colletotrichum Spp. affecting fruits after harvest in Brazil. $J$. Phytopathology, 150: 128-134.

Damm, U., Woudenberg, J. H. C., Cannon, P. F. and Crous, P. W. (2009). Colletotrichum species with curved conidia from herbaceous hosts. Fungal Diversity, 39: 45-87.

Phoulivong, S., Lei, C., Chen, H., McKenzie, 
E. H. C., Abdelsalam, K., Chukeatirote, E. and Hyde, K. D. (2010). Colletotrichum gloeosporioides is not a common pathogen on tropical fruits. Fungal Diversity, 44: 33-43.

Pramod, G., Palani Swami, A. and Srinivas, P. (2007). Post-harvest Diseases of Papaya Fruit in Coimbatore Markets.
Ann. Pl. Protec. Sci., 15(1):140-144. Rahman, M. A., Mahmud, T. M. M., Kadir, J., Rahman, R. A. and Begum, M. M. (2008). Major postharvest fungal diseases of papaya cv. 'sekaki' in Selangor, Malaysia. Journal of Tropical Agricultural Science, 31(1): 27.

\section{How to cite this article:}

Prajapati, H. N. and Patil, R. K. 2020. Cultural and Morphological Variability among the Isolates of Colletotrichum spp. Causes Fruit Rot of Papaya. Int.J.Curr.Microbiol.App.Sci. 9(08): 3344-3353. doi: https://doi.org/10.20546/ijcmas.2020.908.385 